\title{
DUNIA HORIZONTAL DAN DUNIA VERTIKAL DALAM SUPER HILANG, SEGEROBAK SAJAK HAMID JABBAR SUATU TINJAUAN STRUKTURALISME SEMIOTIK
}

\author{
oleh Harris Effendi Thahar \\ FBS Universitas Negeri Padang
}

\begin{abstract}
This article aims at revealing expression of social protest as a horizontal world and religious expression as a vertical one in the anthology of poems Super Hilang by Hamid Jabbar. By means of a structural semiotic approach, it is revealed that the poems gathered in the anthology constitute poems which are heavy with expression of social protest and simultaneously heavy with religious expression. It indicates that they are poems expressing the horizontal world of the poet as a part of his society and the vertical world of the poet as a helpless being in the presence of God.
\end{abstract}

Keywords: horizontal world, vertical world, anthology, poem, semiotic structuralism

\section{A. PENDAHULUAN}

Pepatah mengatakan, "harimau mati meninggalkan belang, gajah mati meninggalkan gading, manusia mati meninggalkan nama." Demikian halnya-penyair Hamid Jabbar-yang wafat dalam usia 55 tahun ketika membaca sajak di Universitas Islam Negeri Syarif Hidayatullah (UN) Ciputat, pukul 23.00, 29 Mei 2004 (Horison, edisi Juli, 2004) meninggalkan ratusan sajak-sajak yang telah ditulisnya hampir di sepanjang hayatnya. Sebagai penyair (sastrawan) Indonesia modern yang telah almarhum, nama Hamid Jabbar tercatat dalam deretan nama-nama penyair Indonesia yang penting setelah generasi Chairil Anwar, Amir Hamzah, dan Subagio Sastrowardojo. Salah satu karyanya yang terpenting adalah Super Hilang, Segerobak Sajak, terbitan Balai Pustaka, 1998 setebal 397 halaman.

Ia wafat dengan cara yang luar biasa ketika sedang "bertugas" membacakan sajaksajaknya di depan khalayak yang terpukau dalam menyimak. Akan tetapi, kepenyairan Hamid Jabbar menjadi penting bukanlah karena peristiwa wafatnya itu, melainkan adalah kekhasan sajak-sajaknya yang sarat dengan protes sosial sebagai bukti keterlibatannya secara penuh dengan kehidupan antarsesama (dimensi horizontal) dan sekaligus intensitasnya menulis sajak-sajak religius sufistik (dimensi vertikal).

Super Hilang, Segerobak Sajak merupakan antologi yang terdiri atas enam kumpulan sajak: Zikrullah, Wajah Kita, Sajak dalam Sajak, Nyanyian Negeri Jajahan, Komputer Teler, dan Mengolah Laila Majnun $H a m b a$, keseluruhannya berisi 143 sajak yang ditulis sejak 1972 hingga 1998. Buku ini telah mendapatkan dua penghargaan sebagai buku terbaik dari Yayasan Buku Utama dan Pusat Bahasa, Departemen Pendidikan dan Kebudayaan, 1998. Selain telah menulis 6 buku kumpulan sajak, Hamid Jabbar masih terus menulis puisi hingga akhir hayatnya. Ia juga menulis skenario, biografi, buku tentang Pertamina dan El Nusa serta editor beberapa buah buku.

Sebagai penyair Indonesia yang tetap produktif mencipta sajak-sajak hingga akhir 
hanyatnya di awal abad ke 21 ini, beberapa sastrawan dan kritikus menuliskan komentarnya tentang kecenderungan sajak-sajak Hamid Jabbar. Menurut Ismail (2004), secara politis Hamid Jabbar pun sensitif, tampak jelas dalam sajaknya "Proklamasi 2" dan "Indonesiaku" yang sempat dicekal di zaman Orde Baru. Hamid juga menulis sajak-sajak yang menunjukkan religiusitas dan kesalehan yang dalam seperti dalam sajak "Assalamu 'alaikum I". Sementara itu, Nadjib (2004) mengatakan bahwa Hamid Jabbar adalah penyair protes sosial. Hampir seluruh puisinya merupakan refleksi kritisisme sosialnya. Pendapat Nadjib juga didukung oleh Damshauser (2004) bahwa sebagai manusia periang, di sisi lain Hamid menderita karena suasana dunia sekelilingnya yang ganas. Ia menjadi bijak dan arif dalam rangka meriangkan dunia dengan menulis kalimat: Walau Indonesia menangis, marilah kita bernyanyi dalam sajak yang dibacakannya terakhir kali.

Komentar-komentar di atas juga menunjukkan bahwa penyair Hamid Jabbar telah meninggalkan karya-karya indahnya sebagai warisan budaya bangsa pada suatu zaman yang dapat dijadikan khasanah kajian sejarah sastra Indonesia di masa depan. Demikian juga halnya penyair-penyair Indonesia terdahulu, telah meninggalkan karyakarya puitis yang memiliki kekhasan masingmasing, seperti Chairil Awar, Amir Hamzah, Subagio Sastrowardojo untuk menyebut beberapa nama yang sudah wafat. Sebagai penyair penting, seyogianya karya-karya Hamid Jabbar mendapat tempat untuk dibicarakan dan diteliti, terutama oleh kalangan pendidik yang akan memperkenalkan dan membelajarkan generasi baru dengan dunia sastra.

Sehubungan dengan hal tersebut di atas, maka rumusan masalah yang akan dipecahkan dalam penelitian ini adalah: Bagaimanakah sajak-sajak Hamid Jabbar dalam antologi Super Hilang, Seerobak Sajak mengungkapkan protes sosial sebagai dunia horizontal keterlibatan penyair dengan kehidupan dunia sekelilingnya dan ungkapan religius sebagai dunia vertikal sebagai bukti kesalehannya?

Sesuai dengan rumusan masalah di atas, tujuan penelitian ini adalah untuk: 1) mengungkapkan protes sosial sebagai dunia horizontal sajak-sajak dalam antologi Super Hilang, Segerobak Sajak Hamid Jabbar dan 2) mengungkapkan religiusitas sebagai dunia vertikal sajak-sajak dalam antologi Super Hilang, Segerobak Sajak Hamid Jabar.

Belakangan ini pengertian sajak sering dipertentangkan dengan puisi, sementara sebagian orang menganggap kedua istilah itu adalah entitas yang sama. Berpegang pada buku antologi Super Hilang, Segerobak Sajak ini, genre sastra yang sedang diteliti ini adalah sajak meski tidak ada salahnya jika juga disebut puisi. Menurut Hasanuddin WS (2002:19-21), sebuah sajak secara formal adalah karya tulis yang ditandai oleh adanya unsur baris/larik dan bait, atau dalam bentuk fisik, dalam larik-lariknya terdapat irama, persamaan bunyi, intonasi, pengulangan dan perangkat lainnya. Sementara dalam bentuk mentalnya terdapat tema, urutan logis, satuan arti yang dilambangkan, dan pola-pola citraan serta emosi. Dengan demikian, sajak adalah puisi yang memiliki bentuk fisik dan bentuk mental.

Atmazaki (1993:7) menyatakan bahwa bahasa menjadi indah karena ada puisi di dalamnya; puisi adalah keindahan yang menjelma dalam kata-kata. Akan tetapi katakata bukanlah penyebab keindahan, melainkan akibat puisi yang dikandungnya. Pendapat ini menyiratkan bahwa puisi bukanlah susunan kata-kata yang membentuk baris dan bait, melainkan sesuatu yang terkandung di dalam kata, baris, dan bait. Dengan demikian, sebuah karya tulis berbentuk prosa dapat mengandung unsur-unsur puisi atau menjadi sebuah prosa yang puitis. Selanjutnya, untuk menjaga konsistensi istilah maka subjek penelitian ini adalah sajak sebagai salah satu genre sastra dan yang membedakannya dengan genre sastra yang lain seperti novel, cerpen, drama, dan esai.

Selain bentuk fisik dan bentuk mental, menurut Hasanuddin WS (2002:36-45) 
setidaknya sajak dibangun oleh empat unsur, antara lain, 1) lapis bunyi, 2) lapis makna (unit meaning), 3) lapis 'dunia', dan 4) lapis metafisis. Lapis bunyi, disebabkan oleh konvensi bahasa yang apabila dibacakan, sebuah sajak memperdengarkan serangkaian bunyi yang kemudian menimbulkan arti atau makna sebagai lapis kedua. Lapis makna, merupakan akibat dari lapis pertama karena, mulai dari fonem, suku kata, frase, dan kalimat, kesemuanya merupakan satuan yang utuh dalam larik atau bait yang menimbulkan arti atau makna. Pada lapis ini, berdampak pada lapis ketiga, yakni menimbulkan citraan dan dunia imajinasi. Lapis 'dunia' sebagai akibat dari lapis makna, menyebabkan pula pembaca/ pendengar untuk menghubungkan sajak tersebut dengan dunia di luarnya, yakni sesuatu yang tidak disebutkan/dituliskan akan tetapi terasa secara implisit. Selanjutnya, lapis metafisis merupakan kelanjutan dari lapis sebelumnya berupa sublimasi dari lapis imajinasi (dunia), yang menimbulkan rasa haru, ngeri, terlibat, atau sesuatu yang membuat pembaca/pendengar berkontemplasi.

Sebagai teori (Ratna, 2004:97-112), dalam pengertian yang lebih luas, semiotika berarti studi sistematis mengenai produksi dan interpretasi tanda, bagaimana cara kerjanya dan bagaimana manfaatnya terhadap kehidupan manusia. Kehidupan manusia dipenuhi oleh tanda, dengan perantaraan tanda-tanda itulah proses kehidupan menjadi lebih efisien, dengan tanda-tanda itu pula manusia dapat berkomunikasi dengan sesamanya. Oleh karena itu manusia disebut juga homo semioticus.

Sebagai ilmu, semiotika berfungsi untuk mengungkapkan secara ilmiah keseluruhan tanda dalam kehidupan manusia, baik tanda verbal maupun nonverbal. Sebagai pengetahuan praktis, pengetahuan terhadap keberadaan tanda-tanda yang dialami dalam kehidupan sehari-hari berfungsi untuk meningkatkan kualitas kehidupan melalui efektivitas dan efisiensi energi yang harus dikeluarkan. Memahami sistem tanda, bagaimana cara kerjanya, berarti menikmati suatu kehidupan yang lebih baik. Di suatu pihak, ilmuwan sosial mencoba memecahkan perbedaan yang terjadi di tengah masyarakat dengan cara menemukan latar belakangnya, memecahkannya secara teoretis, misalnya dengan menerapkan teori konflik. Di pihak lain, ilmuwan sosial juga dapat memecahkannya melalui semiotika, misalnya semiotika interaksi sosial.

Pendekatan Semiotik terhadap penelitian sastra menurut Muhadjir (2000:304305 ) disebut sebagai pendekatan Strukturalisme Semiotik. Semiologi atau semiotik adalah ilmu tentang tanda-tanda dalam bahasa dan karya sastra. Strukturalisme semiotik adalah strukturalisme yang dalam membuat analisis pemaknaan suatu karya sastra mengacu pada semiologi. Selanjutnya, Muhajir menjelaskan, ada dua cara untuk menelaah karya sastra. Pertama: heuristik yang menelaah teks dari tahap demi tahap (kata, larik, an baitbait dalam sajak). Kedua, hermeneutik, yakni dengan membaca secara total/keseluruhan suatu tema atau keseluruhan karya itu sendiri. Penelitian ini akan menggunakan telaah hermeneutik untuk proses analisis pemaknaan berdasarkan prinsip-prinsip semiotik.

Penggunaan kajian semiotik menurut Pierce dalam Eagleton (1989:100-101) juga menggunakan metode struktural untuk menganalisis subjek penelitian sastra. Menurutnya, ada tiga jenis tanda (sign) yang dapat digunakan dalam proses interpretasi, yakni: ikonik, indeksikal, dan simbolik. Ikonik adalah tanda yang menyerupai objeknya atau yang mewakilinya, misalnya foto diri merupakan ikon dari yang punya diri. Indeksikal merupakan tanda yang memiliki hubungan sebab akibat dengan objeknya, misalnya adanya asap merupakan tanda adanya api. Mustahil ada asap tanpa adanya api. Sementara simbolik merupakan tanda secara arbitrer atau konvensional dikaitkan dengan rujukannya, misalnya bendera kuning merupakan simbol dari kematian bagi masyarakat di suatu wilayah budaya, sedangkan di daerah lain menggunakan lambang bendera hitam.

Sementara itu, Barthes (Budiman, 
1999:128-142) menawarkan beberapa tipe analisis semiotik, yakni analisis sekuensial, analisis aktansial, dan analisis fungsional. Untuk kepentingan penelitian ini, analisis hermeneutik digunakan dengan bantuan analisis sekuensial, yakni penafsiran keseluruhan berdasarkan sekuen (bagianbagian) peristiwa.

\section{B. METODE PENELITIAN}

Penelitian ini merupakan penelitian pustaka (desk research), subjek penelitian ini adalah buku antologi sajak Super Hilang, Segerobak Sajak Hamid Jabbar. Fokus penelitian ini dititikberatkan pada muatan unsur protes sosial dan muatan unsur religiusitas dalam sajak-sajak Hamid Jabar yang terhimpun dalam buku antologi Super Hilang dilihat dari sudut strukturalisme semiotik.

Langkah-langkah pengumpulan data penelitian ini dan pembahasannya adalah sebagai berikut. Pertama, melakukan studi pustaka untuk mencari dan mengumpulkan bahan-bahan yang mendukung subjek penelitian. Kedua, membaca keseluruhan teks sajak-sajak yang terhimpun dalam buku subjek penelitian secara seksama. Ketiga, menetapkan sajak-sajak yang memiliki muatan protes sosial dan religiusitas dari tiap-tiap bab. Keempat, melakukan analisis struktural dan memberikan interpretasi menurut teori semiotik yang menggunakan telaah hermeneutik. Kelima, melakukan pembahasan. Tahap akhir, menyimpulkan penelitian.

Untuk mengonfirmasikan keabsahan pengumpulan data penelitian ini, peneliti melakukan konsultasi dengan dosen senior yang memiliki kualifikasi dalam bidang kritik sastra, yakni Prof. Dr. Atmazaki, M.Pd.

\section{HAS IL PENELITIAN DAN PEMBAHASAN}

\section{Hasil Penelitian}

Antologi Super Hilang, Segerobak Sajak ini terdiri atas enam bab yang masingmasing merupakan kumpulan sajak yang pernah terbit, sekaligus juga merupakan pembagian bab secara tematis. Selain itu, sebelum Bab I dan sesudah Bab VI, ada Sajak Pembuka dan Sajak Penutup, masing-masing berjudul "Assalamualaikum I" dan "Astagfirullah". Bab 1, Zikrullah, berisi 9 judul sajak dalam 45 halaman. Bab II, Wajah Kita, berisi 27 judul sajak dalam 46 halaman. Bab III, Sajak dalam Sajak, berisi 46 judul sajak dalam 71 halaman. Bab IV, Nyanyian Negeri Jajahan, berisi 35 judul sajak dalam 77 halaman. Bab V, Komputer Teler, berisi 10 judul sajak dalam 38 halaman dan Bab VI, Mengolah Laila majnun hamba, berisi 14 judul sajak dalam 56 halaman. Sementara itu, setelah Sajak Penutup, juga termuat dua judul esai, masing-masing, "Puisi: Ketidakberdayaan, Pergulatan, Penyerahan dan Kebangkitan? Ya, dalam Iman!" dan "Proses Kreatif Penciptaan Karya Sastra". Sajak-sajak yang terhimpun dalam antologi ini ditulis Hamid Jabbar dalam rentang waktu 26 tahun, yakni sejak 1972 s.d.1998.

\section{a. Protes Sosial sebagai Hubungan Horizontal}

Dalam Bab Zikrullah (1) tidak ditemukan sajak-sajak yang bernuansa protes sebagai hubungan horizontal penyair dengan masalah lingkungan sosialnya. Seperti halnya judul bab ini, semua sajak-sajak yang terhimpun di dalamnya memuat ungkapan "zikir," yakni ungkapan pengakuan yang dalam dari manusia (penyair) terhadap Yang Maha Pencipta. Sementara itu, dalam Bab Wajah Kita (II), sajak "Indonesiaku" yang terdiri atas empat halaman penuh, terlihat nuansa protes sosialnya yang kental. Sajak ini dibuka dengan sebait sajak empat baris yang kemudian diulang-ulang hingga delapan kali, yang ditempatkan sebagai pembatas empat larik narasi dan satu dialog, sekalian juga dipakai sebagai penutup. Berikut petikannya.

$$
\begin{aligned}
& \text { jalan berliku-liku } \\
& \text { tanah-airku } \\
& \text { penuh rambu-rambu } \\
& \text { Indonesiaku }
\end{aligned}
$$

Sajak pembuka "Indonesiaku" ini dengan tipografi pola pantun bagaikan referen 
sebuah lagu yang kemudian diulang-ulang, sekaligus memberi tanda bahwa penyair mengajak pembaca merenungkan sebuah perjalanan hidup kita di tanah air tercinta ini yang penuh rambu-rambu. Kemudian, setelah melewati dua narasi, nada protes mulai menajam pada bangun sajak berupa dialog berikut ini.

"Sebagai supir, saya tak begitu mahir," kata seseorang yang mengaku supir.

"Sebagai penumpang, kita tak begitu lapang"

terdengar seseorang mendengus. "Huss!"

tulis kamus.

"Kita membutuhkan lapang!" teriak orang-orang. "Kita memerlukan kebebasan!" dengus rambu-rambu dan tiang-tiang.

"Tetapi perjalanan harus dilanjutkan," tulis travel-biro dalam iklan. dst, dst.

Dalam Bab Nyanyian Negeri Jajahan $(I V)$, terdapat dua sajak yang memiliki nuansa protes sosial dan kepedulian tinggi penyair terhadap kehidupan berbangsa dan bernegara. Kedua sajak itu adalah "Proklamasi, 2" dan "Super Hilang". Sajak "Proklamasi,2" ini sebenarnya merupakan teks Proklamasi Kemerdekaan Republik Indonesia 1945 yang dipelesetkan secara parodi. Penekanan plesetan dalam sajak ini adalah soal utang negara yang menggunung dan hak asasi manusia.

Sajak "Super Hilang" yang juga menjadi judul dari antologi ini terdiri atas 9 bait yang diawali dengan ungkapan musik "tekdung tralala." Bait-bait sajak ini berbentuk naratif yang prosais, bercerita tentang: pembangunan, hak asasi, dan koruptor. Penyair seperti berbicara kepada bangsanya yang disebut sebagai "bangsa hilang." Setiap bait dimulai dengan "tekdung tralala", sehingga apabila dibacakan terdengar seperti sebuah syair lagu yang penuh irama. Berikut ini petikan bait terakhir dari sajak "Super Hilang."

Tekdung tralala, tekdung tralala! Kepada bangsaku, Bangsa Hilang, inilah
Surat Perintah dari aku, pemimpin kalian! Untuk memudahkan proses pendalaman penghayatannya, maka aku namakan ini Super Hilang! Inilah Super Hilang, Surat Perintah Kepada Bangsa Hilang! Maka aku titipkan rasa kehilangan ini demi kemerdekaan kalian yang sejati!

Karena itu, jangan lupa, supaya kalian melaporkan segala sesuatu yang bersangkutpaut dengan tugas dan tanggung jawab kalian seperti tersebut di atas! Tekdung tralala! Merdeka!

Dalam Bab Komputer Teler (V), sebuah sajak protes sosial yang hanya terdiri dari satu kata dan satu baris, yakni: "Doa Para Penguasa Sepanjang Masa”. Sajak itu adalah,

Doa Para Penguasa Sepanjang Masa

\section{AMAN}

Makna sajak ini tidak dapat ditangkap dengan utuh tanpa mengaitkannya dengan judulnya. Judul dan isi sajak ini menjadi satu kesatuan yang utuh apabila dikaitkan dengan unsur protes secara semiotik, bahwa para penguasa juga manusia yang memerlukan doa untuk melindungi dirinya dari rasa tak aman. Makna selanjutnya, para penguasa merasa punya musuh, yakni orang-orang yang dikuasainya. Penyair sebagai bukan penguasa "merasa" bahwa para penguasa mengamankan dirinya dari yang dikuasainya dengan cara apa pun, termasuk dengan berdoa.

\section{b. Religiusitas sebagai Hubungan Vertikal}

Pada umumnya sajak-sajak Hamid Jabbar yang terhimpun dalam antologi Super Hilang ini merupakan sajak-sajak religius. Betapa pun sajak-sajak yang menyuarakan protes sosial, toh tidak luput dari unsur-unsur religiusnya. Permulaan, antologi ini dibuka dengan sajak pembuka: "Assalamu'alaikum 1" dan ditutup dengan sajak penutup: "Astagfirullah." Hal ini menandakan bahwa 
sajak-sajak yang terhimpun di dalam antologi ini terutama merupakan kekentalan religiusitas kehidupan penyair sebagai hubungan vertikal yang tidak berjarak.

Sajak-sajak yang terhimpun dalam Bab I (Zikrullah), terdiri atas sembilan judul sajak, dimulai dengan Sajak "Setitik Nur" yang ditulis pada awal kepenyairan Hamid Jabbar, 1973. "Setitik Nur" menyiratkan kesadaran kelahirannya ke muka bumi atas kehendak Allah, seperti yang ditulisnya berikut ini.

di dalam waktu dan malam yang mengalirkan gairahnya

lahirlah aku setitik nur pijaranMu dan beranak-pinak

dari

tanda

tanya

Seperti halnya judul bab ini, "Zikrullah" meupakan salah satu sajak yang terpanjang dalam bab ini, terdiri atas 33 bagian yang ditandai dengan nomor. Sajak Zikrullah benar-benar merupakan manifestasi dari puitisasi zikir itu sendiri yang ditulis berirama, seperti terlihat pada Bagian 1 berikut ini.

1.

Kabut samudra rasa, kabut risau dahaga

di dasarnya adalah rindu, bergetar cerah zikirku:

Allah

Kabut samudra rasa, kabut risau dahaga

riaknya adalah senyumku, ombaknya adalah gemuruhku

Allah Allah

Adalah kabut adalah samudra adalah rasa,

dalamnya zikirku berpacu dalamnya rindu:

Allah Allah Allah

Adalah kabut adalah risau adalah dahaga,

dalamnya zikirku berpacu dalamnya rindu:

Allah Allah Allah Allah

Selanjutnya, sajak ini hingga bagian ke-33, tampilan lariknya selalu berbeda satu sama lain, dan pada bagian ke-33 (terakhir), merupakan baris-baris nama Allah, Ya Allah, Lailaha Illallah hingga berakhir dengan tanda seru pada baris ke-17. Sajak ini ditulis 19751977. Sajak yang senada sebenarnya sudah ditulis 1973, yakni sajak "Sebelum Maut Itu Datang, Ya Allah" dan "Aroma Maut" yang ditulis 1978 yang terhimpun dalam Bab II (Wajah Kita).

Selain itu, sajak "Tiba-tiba Sajadahku Bergoyang," yang termuat dalam Bab V (Komputer Teler) merupakan sajak religius yang cukup penting untuk mewakili Dunia Vertikal kepenyairan Hamid Jabbar. Sajak ini terdiri atas lima bait. Bait ke-3 dari sajak ini tertulis seperti berikut.

$$
\begin{aligned}
& \text { O shalatku mungkin kacau } \\
& \text { tapi kuseru juga Dikau: } \\
& \text { "Allah! Allah! Allah! } \\
& \text { betapa goyang aku } \\
& \text { menyaksikan luka } \\
& \text { keimananku!" }
\end{aligned}
$$

Selanjutnya pada bait ke-4 menunjukkan "peristiwa" sajak ini berlangsung di atas sajadah seperti berikut.

Tiba-tiba tertera di sajadahku kata-kata: "Eror! Eror!" seperti dalam layar monitor komputerku. Astaga, tambah pula katakata,

"Sins! Sins!" yang bikin aku menggigil hingga tubuhku bergoyang dan bergoyang

kaku! O aku kaku! Ketaktahuanku ngilu!

Ngilu meraba-raba tombol tolol dalam diriku!

Sajak ini dengan cukup jelas memberikan tanda kesalehan penyair dari narasi yang digunakannya. Dengan demikian, dari hasil 
analisis hermeneutik terhadap keseluruhan sajak-sajak yang mengekspresikan religiusitas penyair menunjukkan bahwa sajak-sajak yang terhimpun dalam kumpulan Super Hilang, Segerobak Sajak ini pada umumnya merupakan ekspresi kekentalan hubungan vertikal penyair Hamid Jabbar dengan Tuhannya.

\section{Pembahasan}

\section{a. Dunia Horizontal}

Setidaknya ada tiga judul sajak dalam buku kumpulan ini yang memiliki kekentalan muatan protes sosial sebagai bukti keterlibatan penyair dengan dunia horizontalnya, yakni: "Indonesiaku," "Super Hilang," dan "Doa Penguasa Sepanjang Masa." Yang dimaksud dengan dunia horizontal di sini adalah dimensi hubungan sosial penyair sebagai warga masyarakat yang di dalamnya tercakup aspek kepedulian antarsesama dan tentu saja dapat berbentuk protes sosial. Hal itu dimungkinkan oleh tanda-tanda indeksikal tentang aneka ekspresi dalam teks-teks ketiga sajak itu yang berfungsi untuk mengansmisikan petandapetanda.

Apabila sajak "Indonesiaku," sebagai judul, lalu dihubungkan dengan bait pertama: /jalan berliku-liku/tanah airku/penuh ramburambu/Indonesiaku/, sebagai intro telah mengantarkan pembaca pada apa yang tak dikatakan (not said). Analisis sekuensial bagian ini telah mengantarkan pembaca sebagai pintu masuk bahwa Indonesia sebagai sebuah negara dan bangsa yang tidak "makmur" dan penuh "kerumitan," sebagai bagian dari teks yang tak dikatakan.

Selanjutnya, narasi bait-bait berikutnya berbicara tentang:/karcis/senja/bus tua/ perjalanan yang terantuk-antuk/ peta/ lukaluka/ sopir yang tidak begitu mahir/ penumpang yang tidak begitu lapang/seribu tanda/ seribu rambu-rambu/ nusantara yang terpotong-potong/ lukamu dan lukaku/, semua itu merupakan refleksi yang begitu kompleks tentang perjalanan sebuah bangsa yang terseokseok. Secara keseluruhan, narasi tentang "perjalanan" yang terlukis di dalam sajak "Indonesiaku" ini dapat dibaca sebagai sebuah indeks bagi protes sosial penyair. Hal itu sesuai dengan apa yang diungkapkan oleh Barthes dalam Budiman (1999:128) bahwa analisis sekuensial merupakan inventorisasi dan klasifikasi tindakan-tindakan (actions) yang homolog dengan lapisan verba yang tersusun sebagai lapisan-lapisan sekuensial. Dengan demikian, dengan jelas, refleksi protes sosial penyair terhadap kondisi yang dihadapi negara dan bangsanya pada saat sajak ini ditulis adalah "kekacauan" yang diciptakan oleh sebuah pemerintahan demi sebuah statusquo telah menyengsarakan bangsanya.

Sajak "Super Hilang," merupakan kelanjutan dari sajak "Indonesiaku" yang telah babak belur agar diperbaiki dengan kesadaran sebagai bangsa. Hal itu ditandai oleh bait pertama sajak ini yang berbunyi:

Tekdung tralala, tekdung tralala! Kepada bangsaku, Bangsa Hilang, ingatlah tingkatan

pembangunan kehilangan di dalam negeri, serta jangan lupa keadaan sosial-

politik-ekonomi regional dan global yang kagak ketulungan betot-betotan antara ketemu dan hilang, dahulu dan sekarang, dahulu dan nanti!

Selanjutnya pada bait kesembilan (terakhir), kesadaran akan tanggung jawab sebagai bangsa untuk mengingatkan antarsesama agar bangkit dari keterpurukan keadaan semakin jelas, namun disampaikan dalam bentuk parodi. Simaklah bait akhir tersebut seperti berikut.

Tekdungtralala,tekdung tralala! Kepada bangsaku, Bangsa Hilang, inilah Surat

Perintah dari aku, pemimpi kalian! Untuk memudahkan proses pendalaman

penghayatannya maka aku namakan ini Super Hilang! Inilah Super Hilang

Kepada Bangsa Hilang!Maka aku titipkan rasa kehilangan ini demi kemerdekaan kalian yang sejati! Karena itu, jangan lupa, supaya kalian 
melaporkan segala sesuatu yang bersangkut paut dengan tugas dan tanggung

jawab kalian seperti tersebut di atas! Tekdung tralala! Merdeka!

Super Semar (Surat Perintah Sebelas Maret 1966) adalah ikon legitimasi pemerintahan Orde Baru yang konon telah hilang hingga saat ini tidak pernah ditemukan. Pemerintahan Orde Baru yang menjalankan pemerintahan dengan gaya kepemimpinan otoriter telah membuat warganegara berada di bawah tekanan politik selama 32 tahun, tak terkecuali yang dirasakan oleh penyair sajak ini. Hal itu terlihat dari tanggal penulisan sajak ini (Sebelas Maret 1996). Protes berbentuk sindirian (atau pelesetan?) ini merupakan bentuk keterlibatan penyair dengan dunia sekelilingnya yang diekspresikan ke dalam sajak "Super Hilang." Sindiran yang cukup sarkastis itu seperti hendak melegitimasi pula segala nasihat-nasihatnya sebagai penyair pemikir nasib bangsa, sekaligus telah menyatakan kesaksian dan visinya tentang dunia nyata.

Sajak "Doa Penguasa Sepanjang Masa", hanya berisi satu kata yang ditulis dengan huruf kapital, yakni: AMAN. Tidak dapat dilacak, mengapa sajak ini menggunakan huruf kapital, terutama yang berhubungan dengan akronim. Akan tetapi, apabila dihubungkan dengan judulnya maka dengan sekali baca dengan cara menyambungkan judul dengan isi, terbacalah:" Doa penguasa sepanjang masa: aman." Dengan demikian, makna kalimat jadian di atas segera dapat ditangkap bahwa, para penguasa di era Orde Baru, bahkan di era Reformasi pun, senantiasa mendoakan dirinya sendiri agar segala tindaktanduknya yang telah merugikan rakyat banyak agar aman dari sanksi berbentuk apa pun. Meski sajak ini ditulis pada era pemerintahan Orde Baru (1993), pada masa sekarang pun terasa masih sangat relevan. Hal itu terbukti betapa banyaknya penguasa bangsa ini, mulai dari menteri, gubernur, bupati/walikota sampai anggota DPR/DPRD dan pejabat-pejabat di sektor lain yang memiliki kekuasaan akhirnya tidak aman dari ancaman pidana korupsi.

\section{b. Dunia Vertikal}

Sebagai penyair, Hamid Jabbar tak dapat mengelak dari "keberadaan dirinya" sebagai manusia di satu pihak dan "Yang Maha Mengatur" di pihak lain sebagai hubungan vertikal yang merupakan suatu keniscayaan. Hal itu terkait dengan keyakinannya sebagai makhluk ciptaan Allah menurut ajaran agama Islam. Dalam sajaknya yang berjudul "Setitik Nur" memberikan sinyal hubungan vertikal yang merupakan suatu keniscayaan antara manusia dan penciptanya itu. Menyadari hal tersebut, penyair Hamid Jabbar tidak punya pilihan lain, kecuali secara total menyerah kepada-Nya dengan sajak "Zikrullah"

Hubungan vertikal itu pun tidak selalu mulus, seperti yang diakuinya di dalam esai penutup di dalam buku antologi ini sebagai ketakberdayaannya sebagai manusia melawan takdir. Ketakberdayaannya itu pun "diakuinya" dalam sajak "Tiba-tiba Sajadahku Bergoyang" yang sesekali tersadar bahwa keimanannya pun bergoyang dengan mengatakan "luka keimananku." Pada bait berikutnya kesadaran itu dilukiskan sebagai "Eror! Eror!"

Puncak dari ketakberdayaan itu sendiri adalah peristiwa kematian (maut) yang harus dilalui manusia. Kesadaran akan maut yang hampir selalu diungkapkan penyair ke dalam sajak-sajaknya bukanlah suatu ketakutan yang berlebihan, akan tetapi sebagai ungkapan tentang keterbatasan duniawi sementara hubungan vertikal itu sendiri kekal adanya. Hal itu terlihat dalam bagian sajak "Sebelum Maut Itu Datang, Ya Allah" berikut ini.

maut datang menerbangkan
ghaibku
masuk ke lubuk pelukan
GhaibMu

ya Allah ya Akbar

Mengutip Heidegger, Mangunwijaya (1982:49) mengatakan bahwa kematian adalah bukti eksistensi manusia yang harus berakhir dengan kematian. Oleh sebab itu, manusia tidak boleh melarikan diri, akan tetapi menyambut 
kematian dengan tenang. Demikianlah halnya dari keyakinan kaum sufi bahwa kematian adalah peristiwa pengheningan keberadaan yang menyatu dengan Yang Maha Gaib. Itulah jalan religius yang telah ditempuh oleh Hamid Jabar dalam sajak-sajaknya, sebagai bukti kesaksiannya terhadap dunia dalam suatu hubungan vertikal yang tak pernah putus.

\section{PENUTUP}

Pembicaraan terhadap antologi sajak Super Hilang, Segerobak Sajak karya Hamid Jabbar ini menggunakan pendekatan Struktural Semiotik. Secara ringkas pembahasan dalam penelitian ini menggambarkan hubungan horizontal dan hubungan vertikal sebagai pusat analisis. Dari bahasan dapat disimpulkan bahwa secara kuantitas, sajak-sajak yang terhimpun di dalam antologi ini merupakan sajak-sajak religius yang melukiskan kekentalan hubungan vertikal penyairnya dengan Yang Maha Pencipta. Meski demikian, jumlah sajak-sajak yang bercorak protes sosial yang lebih sedikit tidak mengurangi intensitas sajak-sajak tersebut terhadap kekuatan hubungan horizontal penyairnya sebagai kualias kepeduliannya terhadap kehidupan manusia di lingkungannya.

Perlu ditambahkan bahwa sajak "Proklamasi 2" yang kuat nada protes sosialnya tidak dibahas dalam penelitian ini karena, sajak tersebut lebih merupakan pelesetan dari teks Proklamasi 17 Agustus 1945. Oleh sebab itu, dari sudut penciptaan dianggap tidak mewakili kepenyairan Hamid Jabbar sesungguhnya. Keistimewaan sajak-sajak Hamid Jabbar dalam antologi ini terletak pada keseimbangan antara hubungan vertikal dan horizontalnya sebagai manusia dan sekaligus sebagai penyair yang telah menambah catatan penting sejarah kesusastraan Indonesia modern.

Sebagai karya sastra modern Indonesia, antologi sajak Super Hilang, Segerobak Sajak karya Hamid Jabar ini seyogianya mendapat tempat bagi guru-guru Bahasa Indonesia di sekolah-sekolah menengah sebagai bahan pembelajaran sastra. Peserta didik di sekolah-sekolah menengah selama ini disinyalir masih saja disuguhi sajaksajak karya penyair Indonesia masa lalu seperti karya-karya Chairil Anwar, Sanusi Pane, dan Amir Hamzah oleh sebagian guru-guru mereka, sementara mereka tidak mengenal karya-karya terbaru dari penyair-penyair yang lahir dan hidup dekat dengan zaman mereka. Tidak berarti karya-karya penyair tersebut di atas tidak penting lagi, akan tetapi semestinya guruguru Bahasa Indonesia juga lebih jeli mencari dan menemukan karya-karya sastra mutakhir dan sesuai zaman tanpa mengabaikan mutu untuk diolah dan dijadikan bahan pembelajaran sastra. Artinya, bahan pembelajaran sastra yang bermutu - dalam hal ini sajak - pada zaman sekarang cukup kaya dan lebih beragam, baik dari segi kuantitas maupun kualitas.

\section{DAFTAR PUSTAKA}

Atmazaki. 1993. Analisis Sajak: Teori, Metodologi, dan Aplikasi. Bandung: Angkasa.

Budiman, Kris. 1999. Kosa Semiotika. Yogyakarta: LkiS.

Eagleton, Terry. 1989. Literary Theory, An Introduction. Oxford: Basil Blackwell Ltd.

Damshauser, Berthold. 2004. "Sang Periang yang Arif, " dalam Horison Majalah Sastra, Edisi Juli 2004.

Hasanuddin, WS. 2002. Membaca dan Menilai Sajak, Pengantar Pengkajian dan Interpretasi. Bandung: Angkasa.

Taufiq Ismail. "Memahami Jarak dan Aroma Ajal," dalam Horison Majalah Sastra, Edisi Juli, 2004.

Muhadjir, Noeng. 2000. Metodologi Penelitian Kualitatif, Edisi IV. Yogyakarta: Rake Sarasin

Nadjib, Emha Ainun. "Kalau Hanya Penyair, Ia Hanya Mati," dalam Horison Majalah Sastra, Edisi Juli, 2004.

Mangunwijaya, YB. 1982. Sastra dan Religiositas. Jakata: Sinar Harapan

Ratna, I Nyoman Kutha. 2004. Teori, Metode, dan Teknik Penelitian Sastra. Yogyakarta: Pustaka Pelajar. 